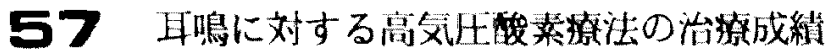

高橋利弥 金田裕治 村井和夫

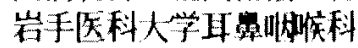

(目的) 高気圧酸素撩法は高気圧環境の中で、酸素を呼吸させ、血中溶解酸素早を增加させることによって、種々の原因によ

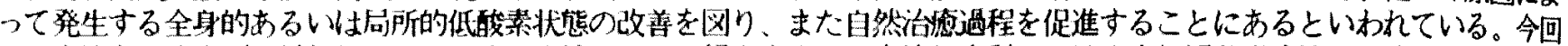

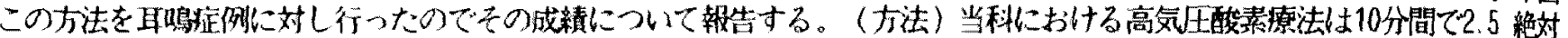

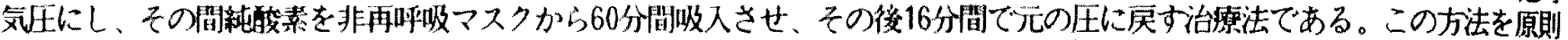
として20回1タールとして行なった。对象は1992年から1995年にわたり種々の治源に抵抗した源因不明の感音難聴を伴った耳 謝症例127例127 耳である。治燎成精はよ効果を消失、改善、不变、患化、変動の5 段階に分け目覚的評価によって半定した。

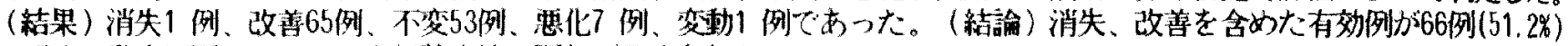

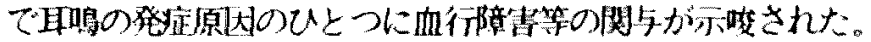

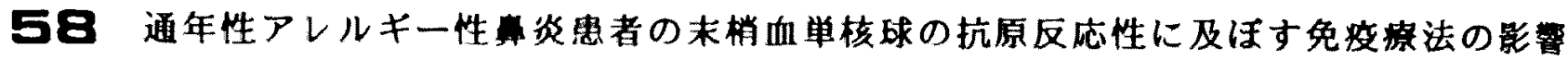

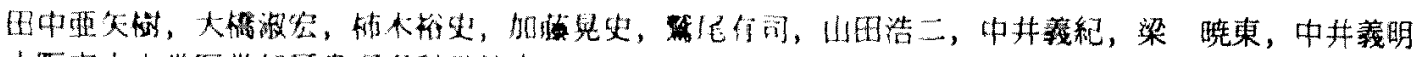

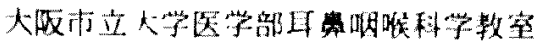

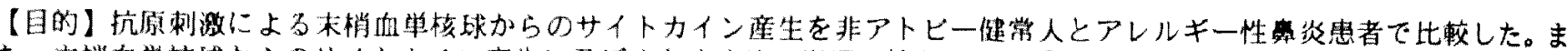

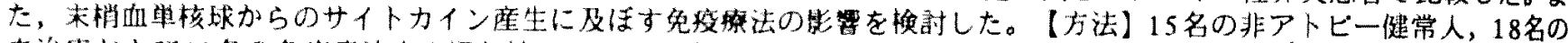

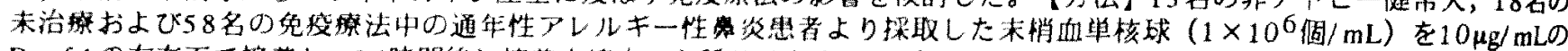

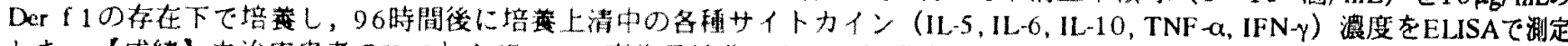

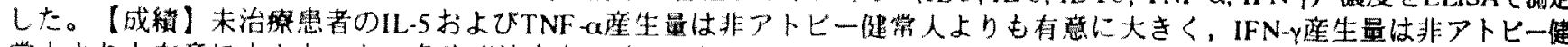

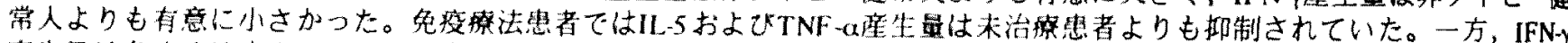

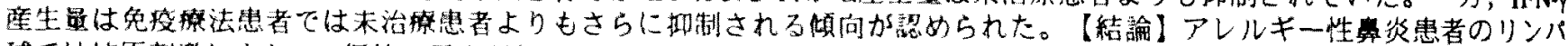

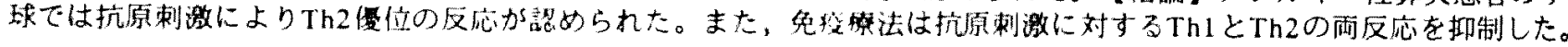

\section{9 無症侯性スキ花粉症患者の末梢血単核球の抗原反応性に関する研究}

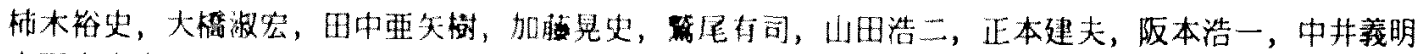

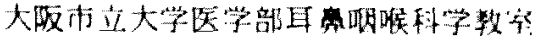

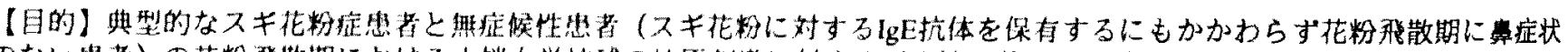

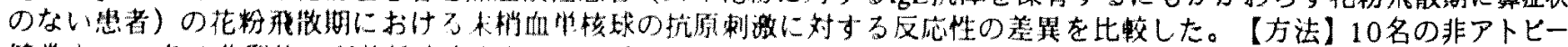

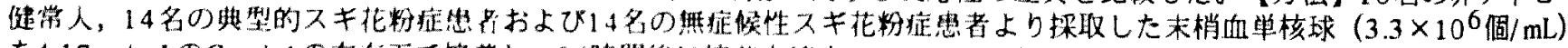

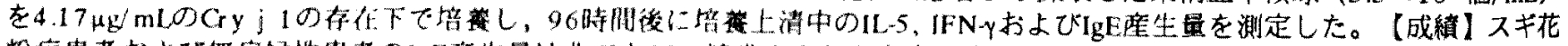

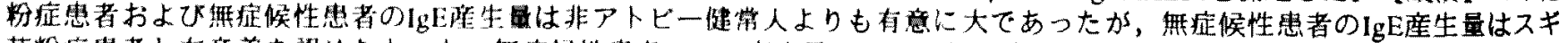

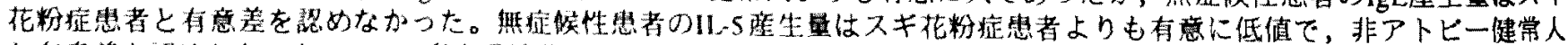

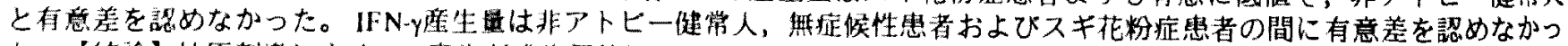

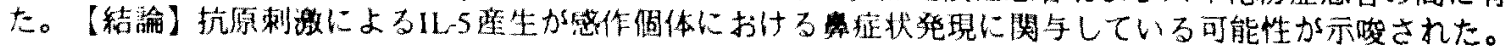

60 マストモテル紼胞の細胞内シグナル伝详に対するプロピオン酸フルチカゾンの効果

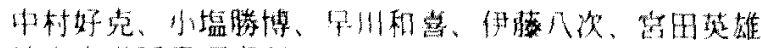

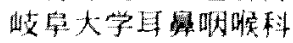

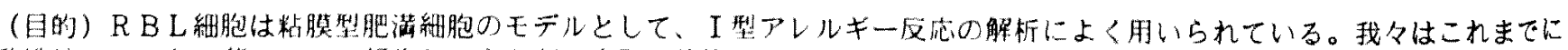

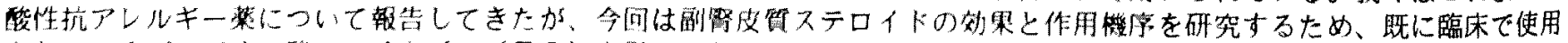

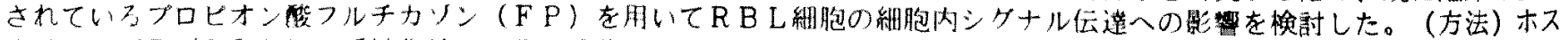

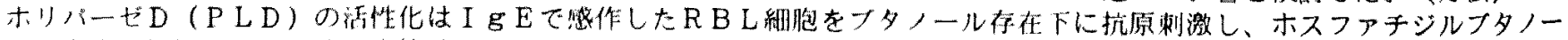

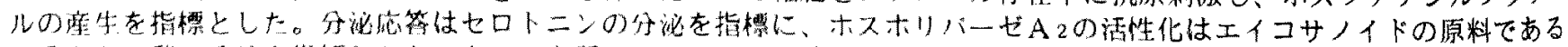
アラキトン酸の分泌を指慓とした。タンパク筫のチロシンリン酸化は抗ホスホチロシン抗体を用いてウエスタンブロットを行

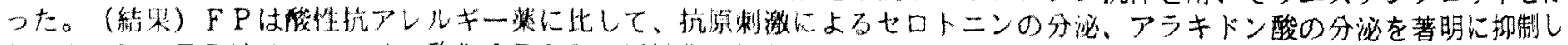

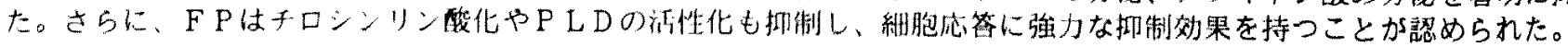

